Primljen / Received: 6.4.2018. Ispravljen / Corrected: 23.7.2018. Prihvaćen / Accepted: 26.7.2018. Dostupno online / Available online: 10.10.2018.

\section{Application of 2D digital image correlation for displacement and crack width measurement on RC elements}

\section{Authors:}

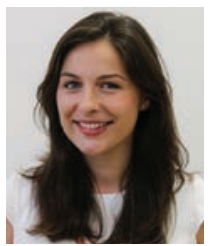

Marina Frančić Smrkić, PhD. CE

University of Zagreb

Faculty of Civil Engineering

Department for Engineering Mechanics

mfrancic@grad.hr

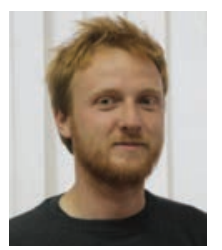

Janko Košćak, MCE

University of Zagreb

Faculty of Civil Engineering

Department for Engineering Mechanics jkoscak@grad.hr

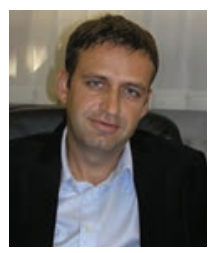

Assoc.Prof. Domagoj Damjanović, PhD. CE University of Zagreb

Faculty of Civil Engineering

Department for Engineering Mechanics ddomagoj@grad.hr

\section{Marina Frančić Smrkić, Janko Koščak, Domagoj Damjanović}

\section{Application of 2D digital image correlation for displacement and crack width measurement on RC elements}

The digital image correlation offers an alternative to the conventional measurement techniques, as it is simple to use and cost effective. The paper presents and analyses displacement and crack width results for reinforced concrete samples, obtained by means of the $2 \mathrm{D}$ digital image correlation and LVDT sensors. The equipment used for digital image correlation includes a plain digital camera, personal computer, and a free version of a commercial photo processing program. Laboratory static test results for three specimens are compared and the 2D digital image correlation method is validated.

Key words:

digital image correlation, DIC, displacements, crack width, experimental research

Prethodno priopćenje

Marina Frančić Smrkić, Janko Košćak, Domagoj Damjanović

\section{Primjena 2D digitalne analize slike za mjerenje pomaka i širina pukotina na $A B$ elementima}

Digitalna analiza slike predstavlja alternativu konvencionalnim metodama mjerenja budući da se radi o jednostavnoj i ekonomski prihvatljivoj metodi. U radu su prikazani i analizirani rezultati ispitivanja pomaka i širina pukotina na armiranobetonskim uzorcima koji su dobiveni 2D digitalnom analizom slike i LVDT osjetilima. Za digitalnu analizu slike korišten je obični digitalni fotoaparat, osobno računalo i besplatna verzija komercijalnog programa za analizu slike. Uspoređeni su rezultati tijekom statičkog ispitivanja u laboratoriju na tri uzorka te je provedena validacija primjene 2D digitalne analize slike.

Ključne riječi:

digitalna analiza slike, DIC, pomaci, širina pukotine, eksperimentalno istraživanje

\section{Marina Frančić Smrkić, Janko Košćak, Domagoj Damjanović}

Vorherige Mitteilung

\section{Anwendung der digitalen 2-D-Bildanalyse zur Messung von Verschiebungen und der Rissbreite an Stahlbetonelementen}

Die digitale Bildanalyse stellt eine alternative konventionelle Messmethode dar, da es sich um eine einfache und wirtschaftliche Methode handelt. In der Abhandlung werden die Untersuchungsergebnisse der Verschiebung und der Rissbreite an Stahlbetonproben dargestellt und analysiert, die durch eine digitale 2-D-Bildanalyse und die LVDT-Sensoren erhalten wurden. Für die digitale Bildanalyse wurden ein einfacher digitaler Fotoapparat, ein Computer und eine kostenfreie Version des kommerziellen Bildanalyseprogramms verwendet. Verglichen wurden die Ergebnisse während der statischen Untersuchung im Labor an drei Proben und es wurde eine Validierung der Anwendung der digitalen 2-D-Bildanalyse durchgeführt.

Schlüsselwörter:

digitale Bildanalyse, DIC, Verschiebungen, Rissbreite, experimentelle Untersuchung 


\section{Introduction}

Measuring displacement and strain on structures and structural elements requires accuracy, simplicity of performance, and cost effectiveness. Digital Image Correlation (referred to below as DIC) offers an alternative or a supplement to conventional measuring techniques, primarily because it is simple to use and cost effective.

DIC is a rather new no-contact optical technique for measuring displacement and strain in $2 \mathrm{D}$ or $3 \mathrm{D}$ mode. It is based on comparison of digital photographs of a test area at different load application stages [1]. The system works by tracking blocks of pixels that need to be random, unique, and with a good range of contrast. For that purpose, the test area is most frequently prepared by can spraying that leaves a random dotted pattern [2], while sometimes the texture of natural surface is sufficient to ensure optimum conditions for DIC use.

DIC has shown a great potential for crack width measurement in concrete as it allows continuous crack width monitoring, especially at the opening phase when cracks are still not visible by nakedeye inspection, microscope, or dye penetration technique [3]. When using LVDT (Linear Variable Differential Transformer) sensors, there is always a possibility that crack will not open within the measurement area or that more than one crack will appear, which can further complicate interpretation of results. In this respect, DIC offers a great advantage by enabling continuous measurement of an unlimited number of cracks within a test area.

In addition, measurements outside of laboratory constitute an additional challenge. In paper [4] it is shown how DIC can be used for in situ measurement of crack width and horizontal and vertical displacements on large structures such as bridges.

The main objective of this research is to assess accuracy of $2 \mathrm{D}$ DIC results as related to results obtained by LVDT sensors. One of DIC advantages when compared to conventional measurement techniques is the cost of equipment. The equipment used in this research includes a personal computer, digital camera and free version of a commercial photo processing program GOM Correlate. Displacement and crack width results obtained during a static test on three specimens are compared and the 2D DIC technique is validated.

\section{Advantages and limitations of 2D digital image correlation}

As noted above, the DIC method offers several advantages when measuring displacements and crack width compared to conventional methods based on LVDT sensors. The great advantage of this method when tracking the crack width is that one can track every crack no matter where it appears. Furthermore, the advantage of this method is that it is contactless, i.e., there are no sensors in contact with specimen that might affect test results. The problem with the use of many conventional measurement sensors lies in cable management but also in the cost of experiment since each sensor is related to a single channel on the data acquisition device. In addition, LVDT sensors have a limited measurement range, and so sensors can often detach from the test sample at higher displacements and strains. This problem is avoided when the DIC method is used, and it is possible to measure the strains and crack widths even at large displacements.

The greatest advantage of this test method is the price of the test itself. Namely, for the DIC test, only a digital camera, a personal computer and a free photo processing program (in this case GOM Correlate) are required. Measurement of displacement and crack width with LVDT sensors is considerably more expensive due to sensor prices, but also to data acquisition system.

However, the 2D method of digital image correlation has several potential sources of error that have to be taken into consideration when conducting the experiment. Furthermore, one must be aware of the limitations of the method in terms of data accuracy, especially if some of the error sources listed below [5] are ignored. It should be noted that most of these errors do not apply to the 3D digital image correlation method, but such test setup is much more complicated and requires expensive equipment (more cameras, advanced image processing software, etc.).

\subsection{Great impact of reference photo on test results}

All measurement results, obtained by the $2 \mathrm{D}$ digital image correlation, represent the relative relationship of the test specimen state at some point, with respect to the initial state. For that reason, it is very important that the reference photograph is taken at the beginning of the test and that the camera position does not change from the moment when the reference photograph is taken. Each unwanted shift of camera during the recording causes a mistake that cannot be removed in the $2 \mathrm{D}$ digital image analysis. In order to reduce to minimum the camera shift during the testing, the test camera was controlled remotely over a personal computer, which was situated a few meters away. Furthermore, it is necessary to ensure that there is no movement, vibration, or airflow near the camera that would cause it to move or shake.

\subsection{Camera lens distortion}

Figure 1 shows an object (Figure A) and the image of the same object shot with the lens having a considerable distortion (Figure B). Let us imagine the movement of two points on the object is followed. One of these points is situated at the edge of the frame (the red arrow), and the other in the middle of the frame (the blue arrow). Additionally, let us consider an example in which the entire object moves in downward vertical translation, when the actual shift of points (red and blue arrows) is the same. It can be noticed that the measured shifts (Figure $B$ ) are not the same as the measured point shift at the edge is smaller than the real one, and the measured shift in the middle of the frame is larger than the real one. This source of error can be avoided by positioning the specimen in the middle of the frame where the effect of distortion is smaller. In addition, it would also be appropriate to use the focal lengths at which 
the distortion is the smallest. There are numerous tests for commercial camera lenses that show lens distortion as related to focal length. These tests enable finding the focal length of the lens where the distortion value is the lowest. a)

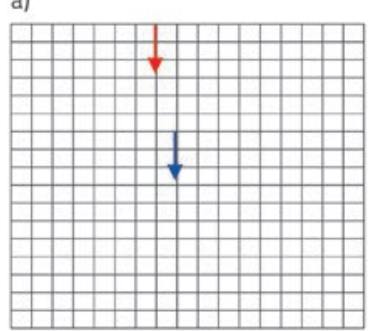

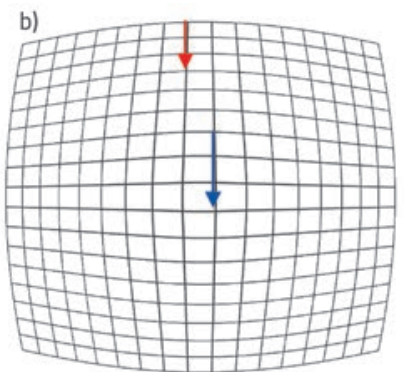

Figure 1. Camera lens distortion

\subsection{Change in distance between specimen and camera}

Let us assume that we measure some physical parameter on a specimen that is positioned at the distance $\mathrm{g}_{1}$ from the camera (Figure 2).

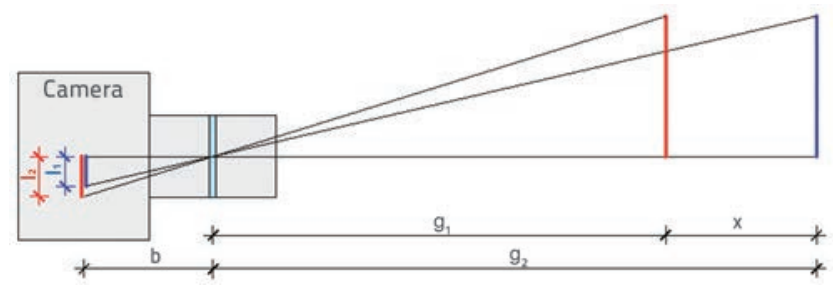

Figure 2. Change in distance between specimen and camera

The projection of an arbitrary specimen dimension on the camera sensor has a length of $\mathrm{I}_{1}$. If the distance between the test specimen and the camera changes for a given $x$, the projection of the same dimension on the specimen amounts to $I_{2}$ $\neq I_{1}$. The error resulting from the change in the distance of the test specimen from the lens of the camera can be expressed as:

$\varepsilon=\left(\frac{g_{1}}{g_{1}-x}\right) \cdot 100 \%=\frac{g_{1}}{g_{2}} \cdot 100 \%$

\subsection{Deviation from perpendicular position of specimen to optical axis of camera}

Let us assume that the test specimen is not placed perpendicular on the optical axis of the camera or that the camera is rotated relative to the test specimen. Figure 3 shows that the vertical displacement of the point on the specimen causes a change in the distance of the observed point from the lens of the camera, therefore $g_{2}>g_{1}$. The error of such test setup can also be calculated using expression (1), where $g_{2}$ depends on the angle of deviation between the camera optical axis and the test specimen and the vertical displacement of the observed point $d$.

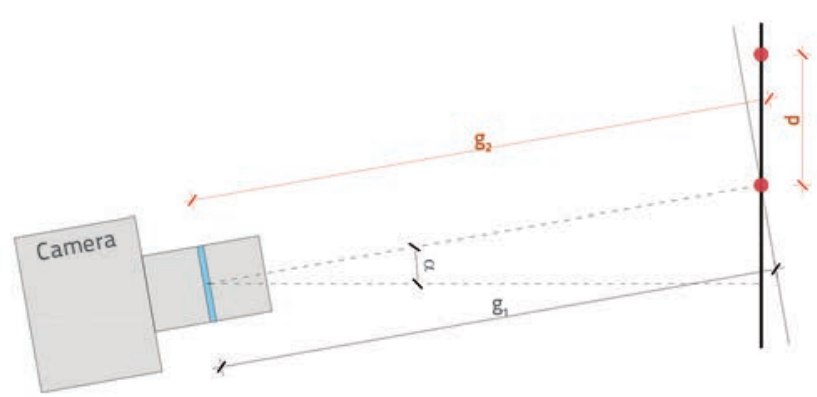

Figure 3. Test setup when optical axis of the camera is not perpendicular to test specimen

\section{Experimental research}

\subsection{Test specimens}

The testing was conducted on three slab specimens measuring $240 \mathrm{~cm} \times 50 \mathrm{~cm} \times 18.5 \mathrm{~cm}$. The specimens were reinforced in longitudinal direction with steel rebars $\mathrm{B} 500 \mathrm{~B}, 10 \mathrm{~mm}$ and $12 \mathrm{~mm}$ in diameter, figure 4. Transverse reinforcement was installed only for ease of handling, as the load was applied in one direction only. Specimens were fabricated in steel formwork directly on vibrating table in the plant. They were covered with plastic sheets in order to reduce sudden evaporation of water, and to maintain the temperature. After four days, specimens were demoulded and stored at a temperature of approximately $10^{\circ} \mathrm{C}$ until transport to the Structural Testing Laboratory of the Faculty of Civil Engineering in Zagreb.

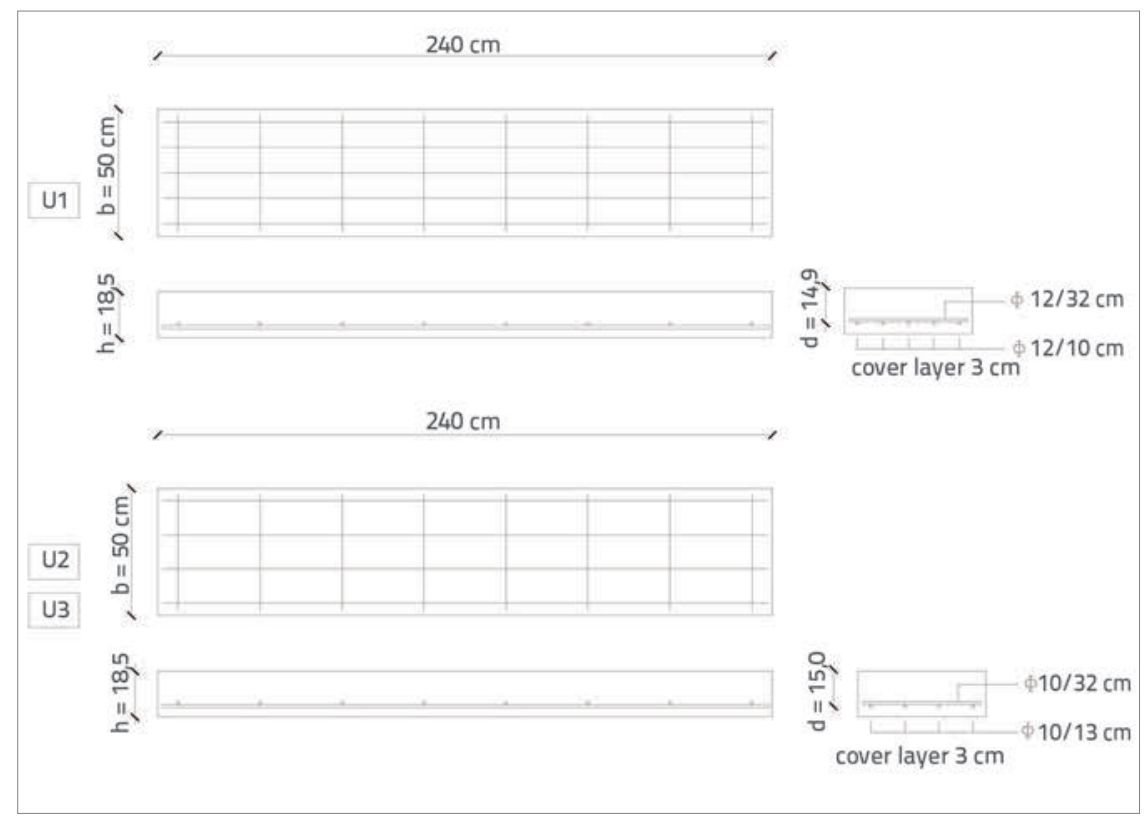

Figure 4. Reinforcement plan 


\subsection{Material properties}

Specimens were made of Hybrid Steel Fibre Reinforced Concrete (HSFRC). It is a concrete reinforced with a combination of industrial and recycled steel fibres [6]. River aggregate, with the maximum grain size $16 \mathrm{~mm}$, and cement type CEM II/A-M (S-V) $42.5 \mathrm{~N}$, were used for fabrication of concrete. The polycarboxylic ether superplasticiser with long lateral chains was used to achieve concrete workability corresponding to class S4 (slump $160 \mathrm{~mm}$ - $210 \mathrm{~mm}$ ). Manufactured steel fibres used for reinforcement were straight with hooked ends, $35 \mathrm{~mm}$ in length and $0.55 \mathrm{~mm}$ in diameter. Recycled steel fibers $20 \mathrm{~mm}$ in average length and $0.15 \mathrm{~mm}$ in diameter were also used. Mix design is shown in table 1.

\section{Table 1. Mix design}

\begin{tabular}{|l|c|}
\hline Aggregate $\left[\mathrm{kg} / \mathrm{m}^{3}\right]$ & 1794 \\
\hline Cement $\left[\mathrm{kg} / \mathrm{m}^{3}\right]$ & 370 \\
\hline Water $\left[\mathrm{kg} / \mathrm{m}^{3}\right]$ & 170 \\
\hline w/c ratio & 0.46 \\
\hline Superplasticiser $\left[\mathrm{kg} / \mathrm{m}^{3}\right]$ & 2.22 \\
\hline Manufactured steel fibres $\left[\mathrm{kg} / \mathrm{m}^{3}\right]$ & 20 \\
\hline Recycled steel fibres $\left[\mathrm{kg} / \mathrm{m}^{3}\right]$ & 20 \\
\hline
\end{tabular}

Table 2. Compressive strength on concrete cubes

\begin{tabular}{|c|c|c|c|}
\hline \multirow{2}{*}{$\begin{array}{c}\text { Slab } \\
\text { mark }\end{array}$} & $\begin{array}{c}\text { Specimen } \\
\text { mark }\end{array}$ & $\begin{array}{r}\text { Compressive } \\
\text { strength [MPa] }\end{array}$ & $\begin{array}{r}\text { Average value of } \\
\text { compressive strength [MPa] }\end{array}$ \\
\hline \multirow{2}{*}{ U1 } & 1 & 51.60 & \\
\cline { 2 - 3 } & 2 & 51.55 & \multirow{2}{*}{51.63} \\
\cline { 2 - 3 } & 3 & 51.73 & \\
\multirow{2}{*}{ U2 } & 1 & 53.03 & \\
\cline { 2 - 3 } U3 & 2 & 51.85 & \multirow{2}{*}{5} \\
\cline { 2 - 3 } & 3 & 51.87 & \\
\hline
\end{tabular}

Table 3. Mechanical properties of steel rebars

\begin{tabular}{|l|c|c|}
\hline Property & $\Phi 12 \mathbf{m m}$ & $\Phi 10 \mathbf{m m}$ \\
\hline Yield strength $\mathrm{R}_{\mathrm{p} 0,2}[\mathrm{MPa}]$ & $505 \pm 2$ & $540 \pm 4$ \\
\hline Tensile strength $\mathrm{R}_{\mathrm{M}}[\mathrm{MPa}]$ & $621 \pm 1$ & $624 \pm 3$ \\
\hline Total elongation $\mathrm{A}_{\mathrm{t}}[\%]$ & $14.0 \pm 1.0$ & $12,5 \pm 1.0$ \\
\hline Modulus of elasticity $\mathrm{E}[\mathrm{GPa}]$ & 182.3 & 182.7 \\
\hline
\end{tabular}

\subsection{Test setup}

Specimens were subjected to a four-point bending test, with supports placed $220 \mathrm{~cm}$ apart. Slabs were continuously supported over their width with steel rollers $40 \mathrm{~mm}$ in diameter. Load was applied to specimens via two steel plates measuring $50 \mathrm{~cm} \times 10$ $\mathrm{cm} \times 3 \mathrm{~cm}$. Before the testing, special care was taken to ensure centrical placing of every specimen and symmetrical positioning of the loading set. The test setup is shown in Figure 5. Loading was applied using the $600 \mathrm{kN}$ hydraulic actuator Zwick/Roell, with the displacement control rate of $3 \mathrm{~mm} / \mathrm{min}$, in $25 \mathrm{kN}$ increments, with unloading. Vertical displacements were measured with LVDT sensors produced by HBM, type WA100 mm and type WA10 $\mathrm{mm}$. Displacements were measured at the bottom side of the specimen along two axes (V1 and V2) and at the upper side of the specimen over the supports (L1-L4) in order to control the total displacement and settlement of the setup. Relative strains were measured on compressive and tensile sides of the specimen with LVDT sensors on the $200 \mathrm{~mm}$ measurement base in the middle of the span. Disposition of measurement points is shown in Figure 6. The testing was conducted at room temperature and at an average specimen age of three months.

The testing was conducted in parallel with the conventional system for displacement and strain measurement with LVDT sensors, and using the $2 \mathrm{D}$ digital image correlation. One side of the specimen (side A) was prepared for measurement by spraying paint on the surface to form of a random point specimen, Figure 7.

During concrete mixing, three 150 $\mathrm{mm}$ cube specimens were taken for compressive strength testing. Compressive strength was determined according to HRN EN 12390-3 [7], Table 2.

Steel rebar properties were determined according to HRN EN ISO 156301:2010 [8] and HRN EN ISO 6892$1: 2009$ [9] on three specimens for each diameter type. Results are shown in Table 3.

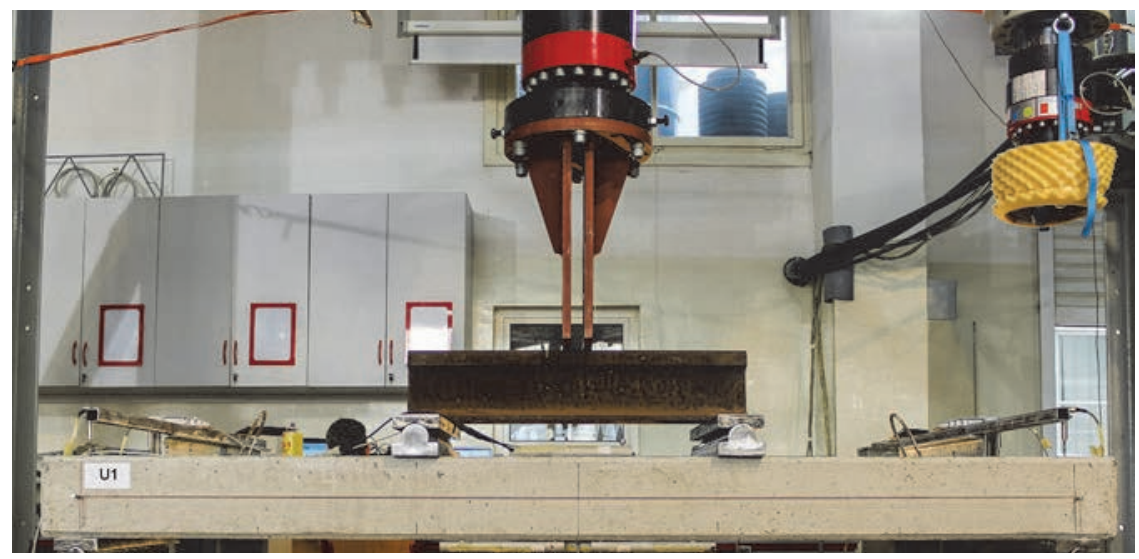

Figure 5. Test setup 

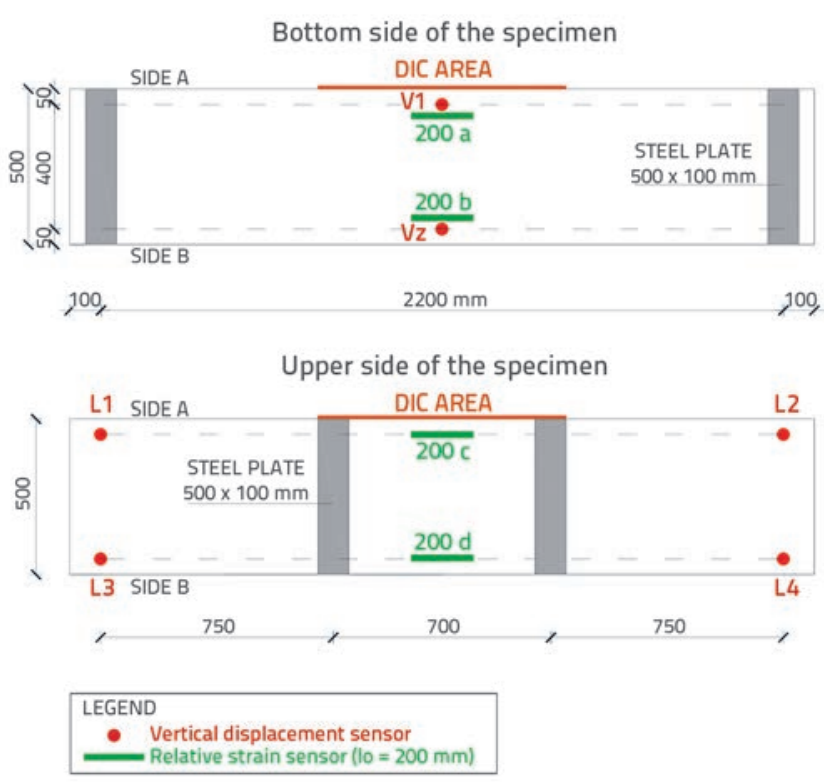

Figure 6. Disposition of measurement points

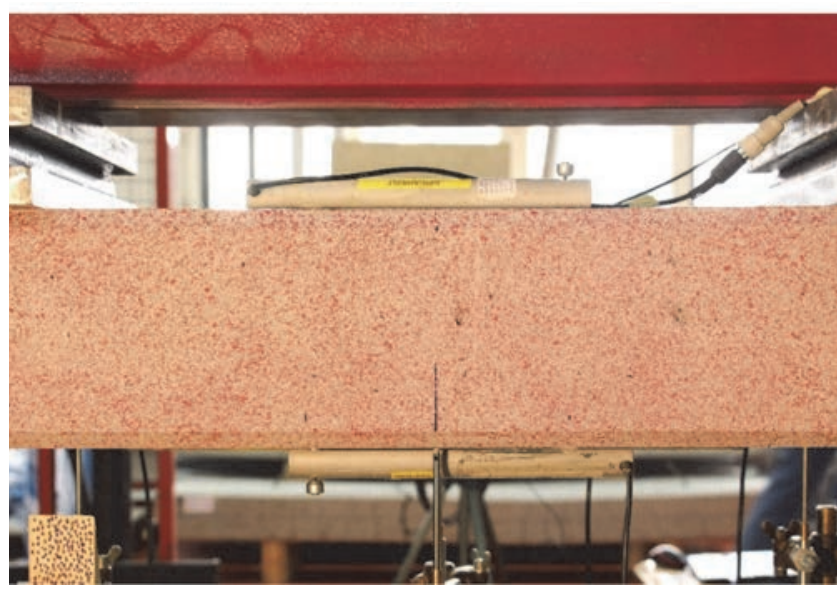

Figure 7. Test specimen prepared for Digital Image Correlation

During the test, the Canon EOS 700D digital SLR camera with the resolution of $5184 \times 3456$ pixels (18 megapixels) was used to take photographs for digital analysis. The camera was equipped with the Canon EF-S lens with the focal length ranging from $18 \mathrm{~mm}$ to $55 \mathrm{~mm}$. Maximum aperture of the lens is $F / 3.5$ for the focal length of $18 \mathrm{~mm}$, and $F / 5.6$ for the focal length of $55 \mathrm{~mm}$. During the test, the digital camera was attached to the tripod with a $10 \mathrm{~kg}$ weight, for camera stabilization and vibration reduction. The tripod was placed approximately $1 \mathrm{~m}$ away from the specimen and the optical axis of the camera was directed perpendicular to the surface of the specimen. The camera was connected to the computer and controller remotely via digiCam Control software, which allows manual exposure setup (aperture, shutter speed and ISO). The exposure was the same for all photographs taken during the experiment. Exposure settings are shown in Table 4.
Table 4. Camera setup

\begin{tabular}{|l|c|}
\hline Shutter speed & $1 / 25 \mathrm{~s}$ \\
\hline Aperture & $\mathrm{F} / 5.6$ \\
\hline ISO sensitivity & ISO 800 \\
\hline Focal length & $42 \mathrm{~mm}$ \\
\hline
\end{tabular}

Photographs of the test specimen were recorded every 10 seconds during the test. Since this is a static test, this sampling frequency is considered to be sufficient for data collection. The camera settings shown in Table 4 were selected based on image sharpness and lens distortion analysis. According to results shown in [10], the focal length of $42 \mathrm{~mm}$ was chosen as it exhibits a minimum amount of distortion. In addition, the F/5.6 value was selected for aperture, which is the area of the highest lens sharpness (sweet spot of the lens used). Sensor sensitivity was adjusted to ensure sufficient photo brightness with minimum noise output at ISO 800. A free version of the commercial software package GOM Correlate was used for the processing of digital images. The commercial program GOM Correlate enables comparison of images taken at some point in time with any other image taken at a different point in time. In this paper, all photographs taken during the experiment were compared with the reference image taken at the beginning of the test. With this test setup, it is important to ensure that there is no displacement and strain at the reference photograph, i.e. that the photograph is taken prior to the testing. All subsequent photographs represent the state of the specimen relative to the reference image.

\section{Test results}

As earlier mentioned, the testing was conducted on three specimens. The corresponding results are shown in form of crack widths and vertical displacements. The crack width on the measurement base of $200 \mathrm{~mm}$, and vertical displacement in the middle of the span, were measured with DIC technique, and also with LVDT sensors. Vertical displacement results in point V1 and crack width in point 200 a, Figure 6, obtained by DIC method and by LVDT sensors, are compared below.

Table 5 shows all measurement points for both methods: a) Digital Image Correlation - GOM and b) LVDT sensors - HBM. Figure 8 shows measurement points in the GOM Correlate programme. The point in which vertical displacement was measured was placed above LVDT sensor (point Ui-V1GOM), and the virtual extensometer was placed in a way to include the same area as LVDT sensor for crack width measurement (point Ui-200-GOM). As the programme is capable of monitoring an unlimited number of points, vertical displacements at several points selected at random are also shown. 
Table 5. Measurement points with description

\begin{tabular}{|c|c|c|}
\hline Specimen & Measurement point & Description \\
\hline \multirow{10}{*}{$\begin{array}{l}\text { Specimen } i \\
(i=1,2,3)\end{array}$} & $\mathrm{Ui}-\mathrm{V} 1-\mathrm{GOM}$ & Vertical displacement in the middle of the span - DIC. \\
\hline & $\mathrm{Ui}-\mathrm{V} 1-\mathrm{HBM}$ & Vertical displacement in the middle of the span - LVDT sensor. \\
\hline & $\mathrm{Ui}-200-\mathrm{GOM}$ & Crack width on measurement base 200 mm - DIC. \\
\hline & $\mathrm{Ui}-200-\mathrm{HBM}$ & Crack width on measurement base 200 mm - LVDT sensor. \\
\hline & $\mathrm{Ui}-\mathrm{P} 1$ & \multirow{6}{*}{ Crack width of selected cracks - DIC. } \\
\hline & $\mathrm{Ui}-\mathrm{P} 2$ & \\
\hline & $\mathrm{Ui}-\mathrm{P3}$ & \\
\hline & $\mathrm{Ui}-\mathrm{P} 4$ & \\
\hline & $\mathrm{Ui}-\mathrm{P} 5$ & \\
\hline & $\mathrm{Ui}-\mathrm{P} 6$ & \\
\hline
\end{tabular}

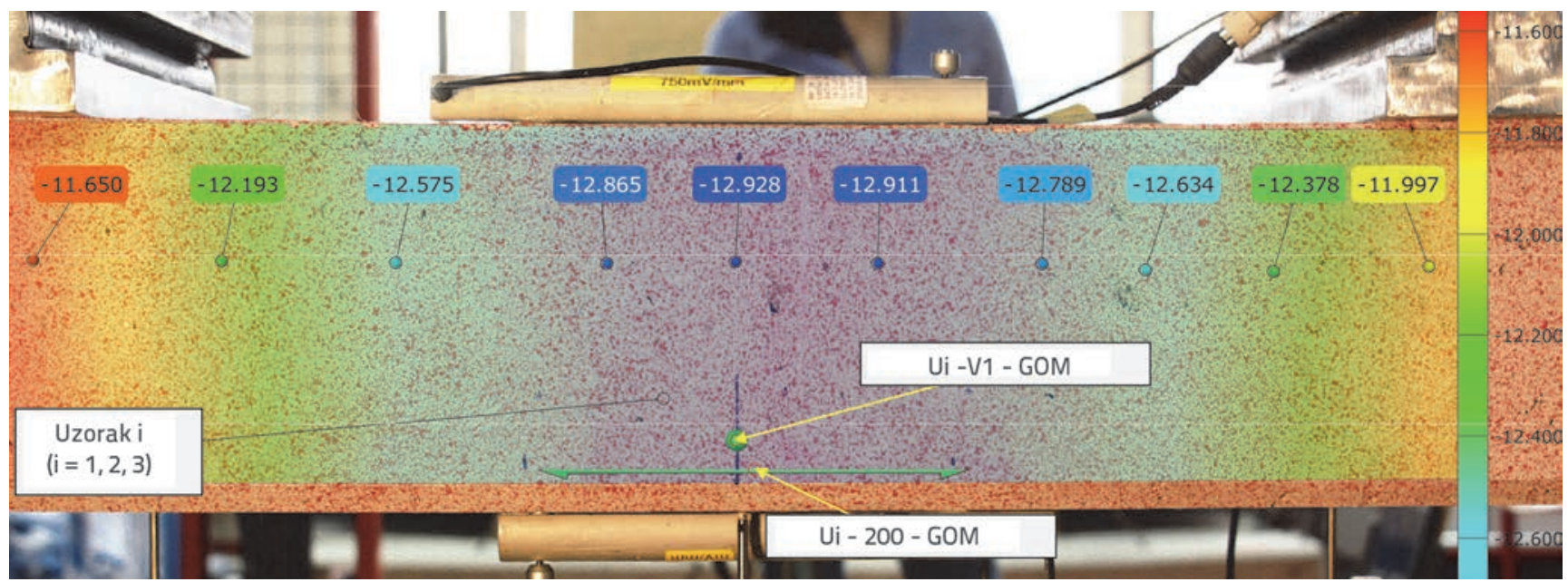

Figure 8. Measurement points and graphical image of vertical displacements at several points obtained by DIC on one specimen

Figures 9 to 14 show the comparison of the vertical displacement measurement results in the middle of the span obtained according to two methods for all three specimens. The results are shown in a form of displacement-time and load-displacement diagram. It can be noted that, for all three specimens, the DIC method shows good agreement with conventional measuring

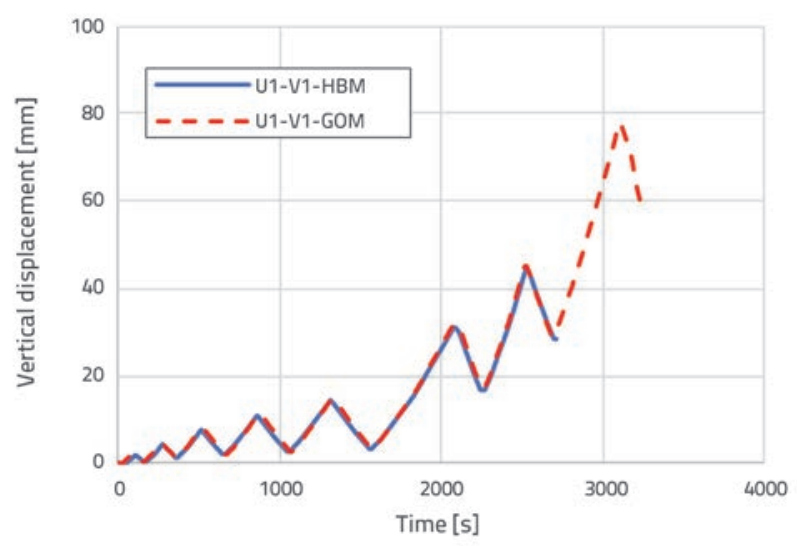

Figure 9. Vertical displacement comparison for specimen U1 method using LVDT sensors. One of advantages of the DIC method lies in its possibility to monitor every crack separately. Figures 15, 16, and 17 show graphical crack display obtained by DIC for all three specimens. Measurement points for crack width monitoring were placed as virtual extensometers over six biggest cracks on each specimen.

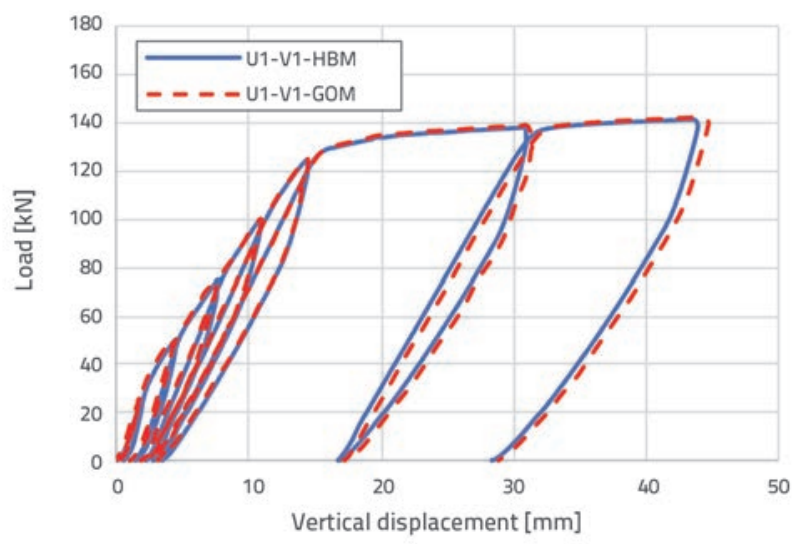

Figure 10. Load-displacement diagram comparison for specimen U1 


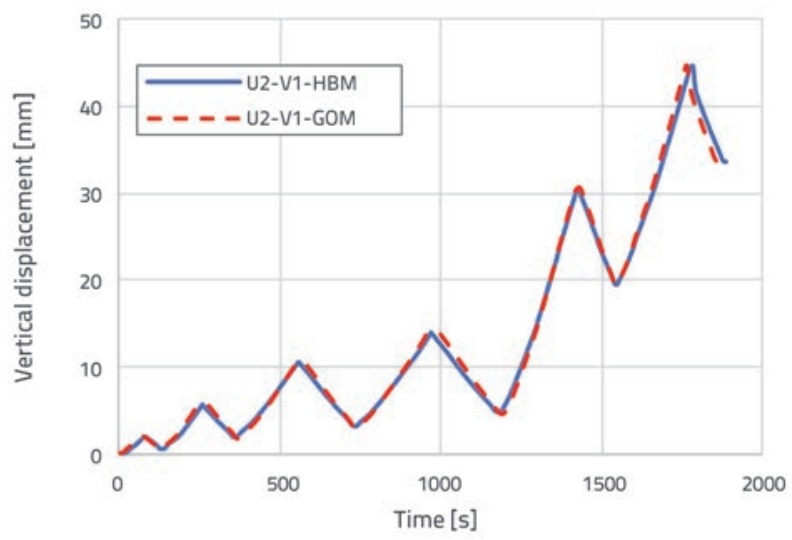

Slika 11. Vertical displacement comparison for specimen U2

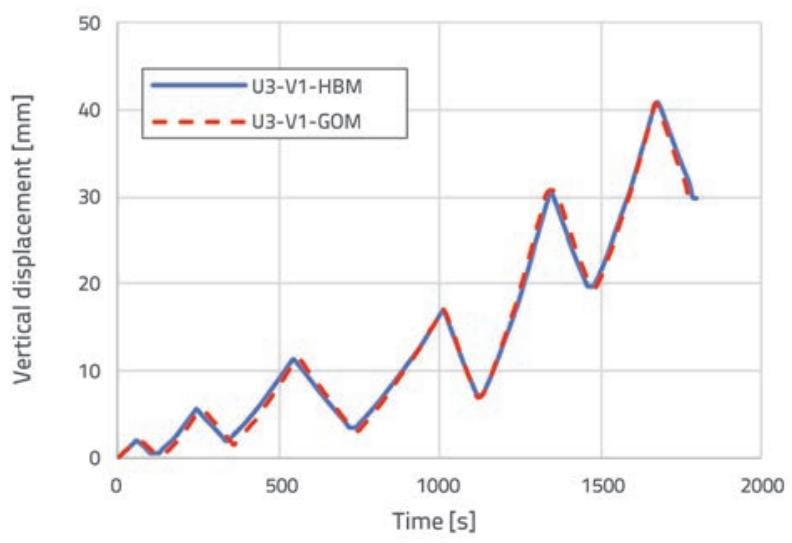

Figure 13. Vertical displacement comparison for specimen U3

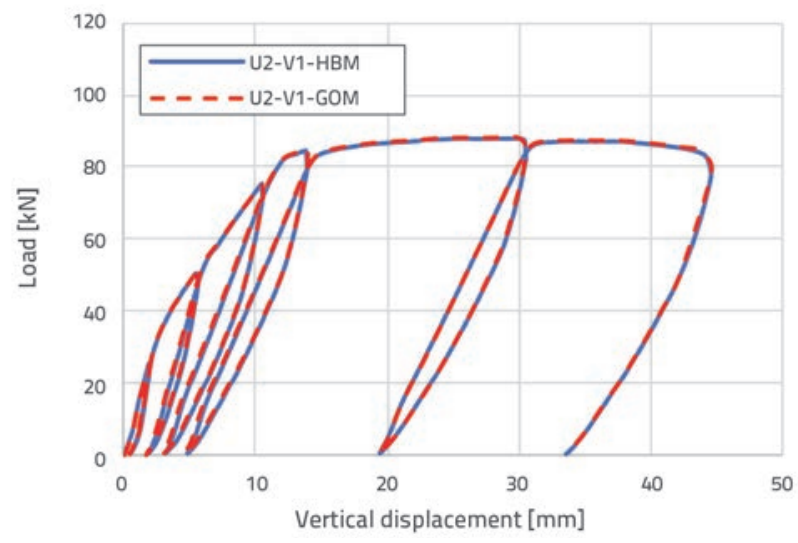

Slika 12. Load-displacement diagram comparison for specimen U2

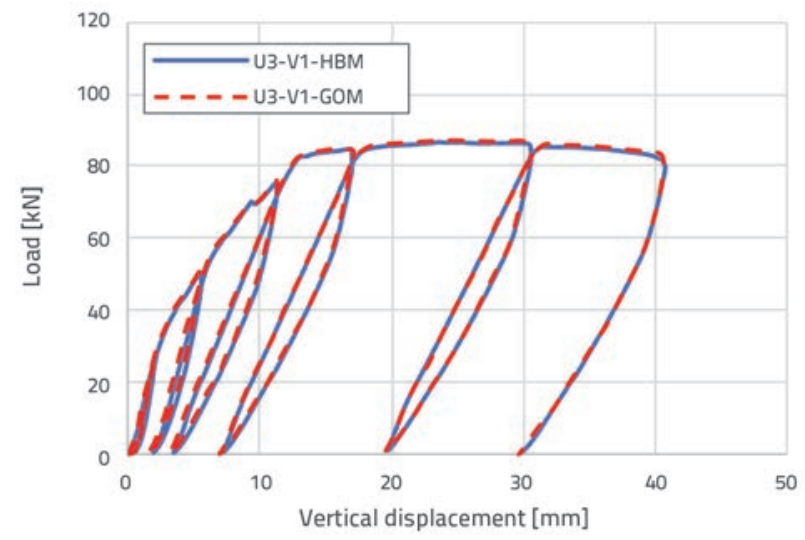

Figure 14. Load-displacement diagram comparison for specimen U3

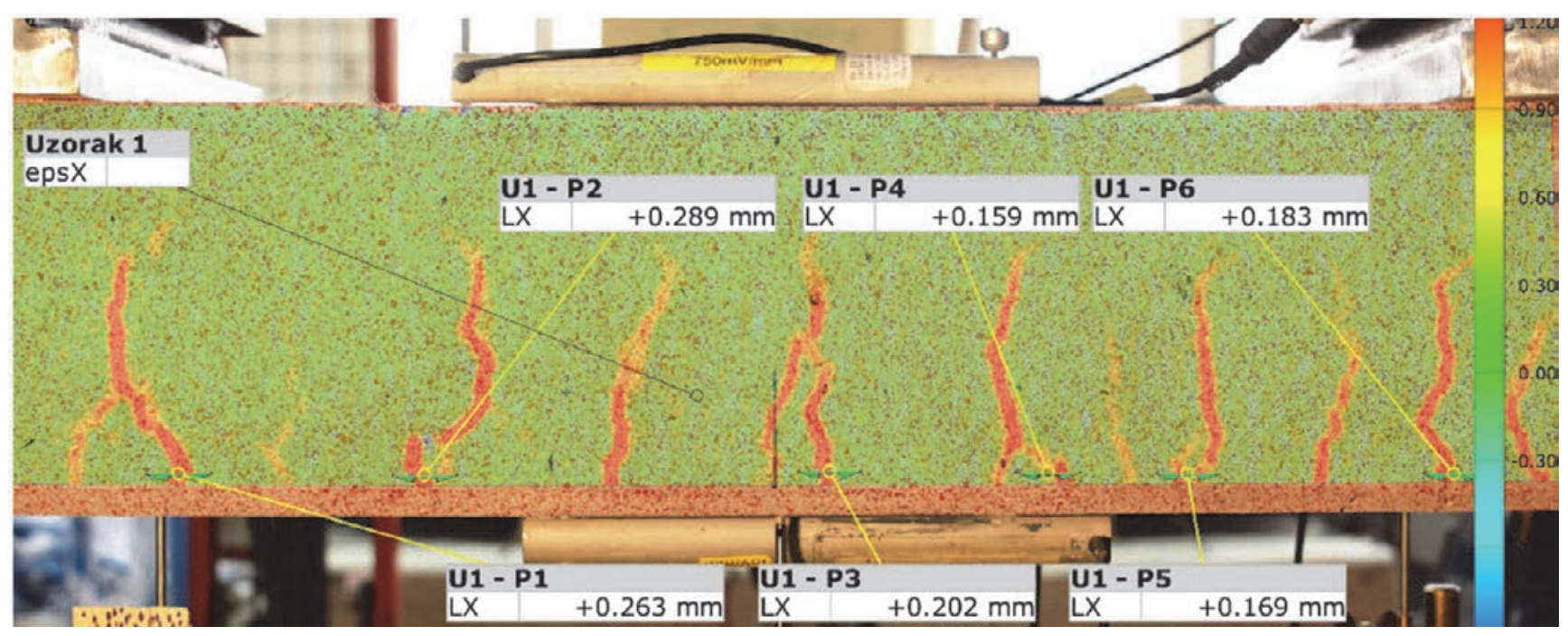

Figure 15. Graphical crack display obtained by DIC at specimen U1 


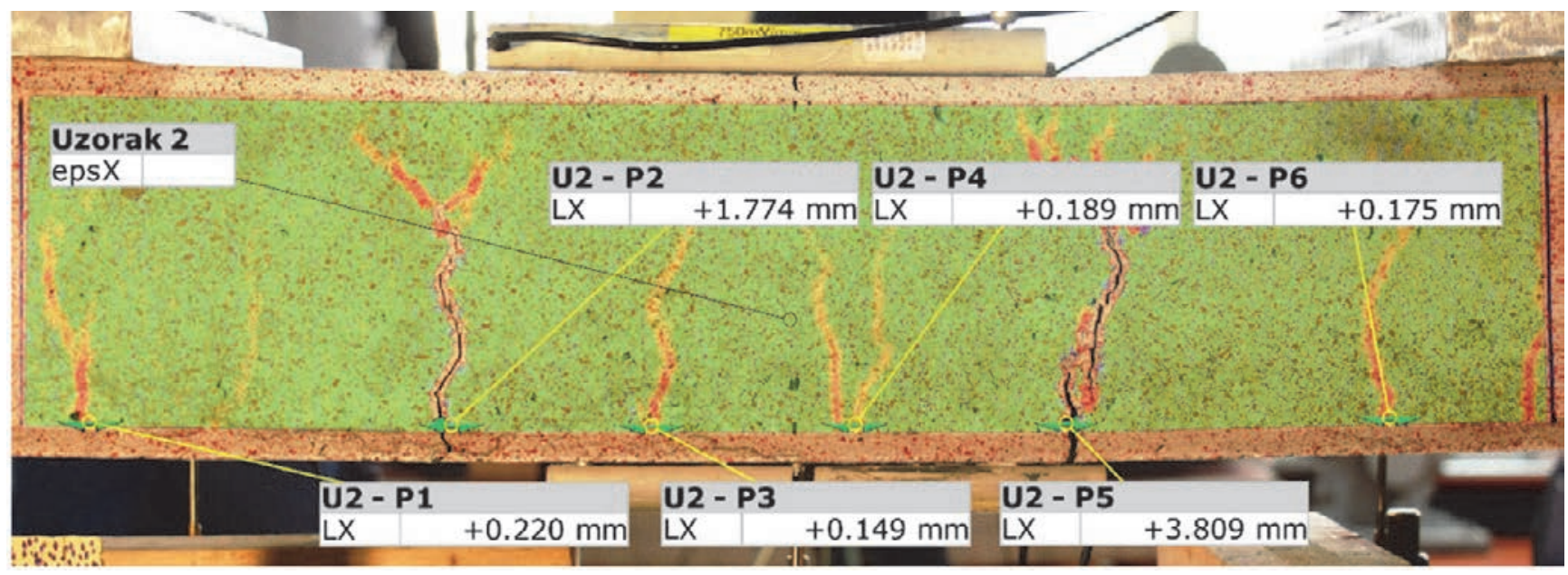

Figure 16. Graphical crack display obtained by DIC at specimen U2

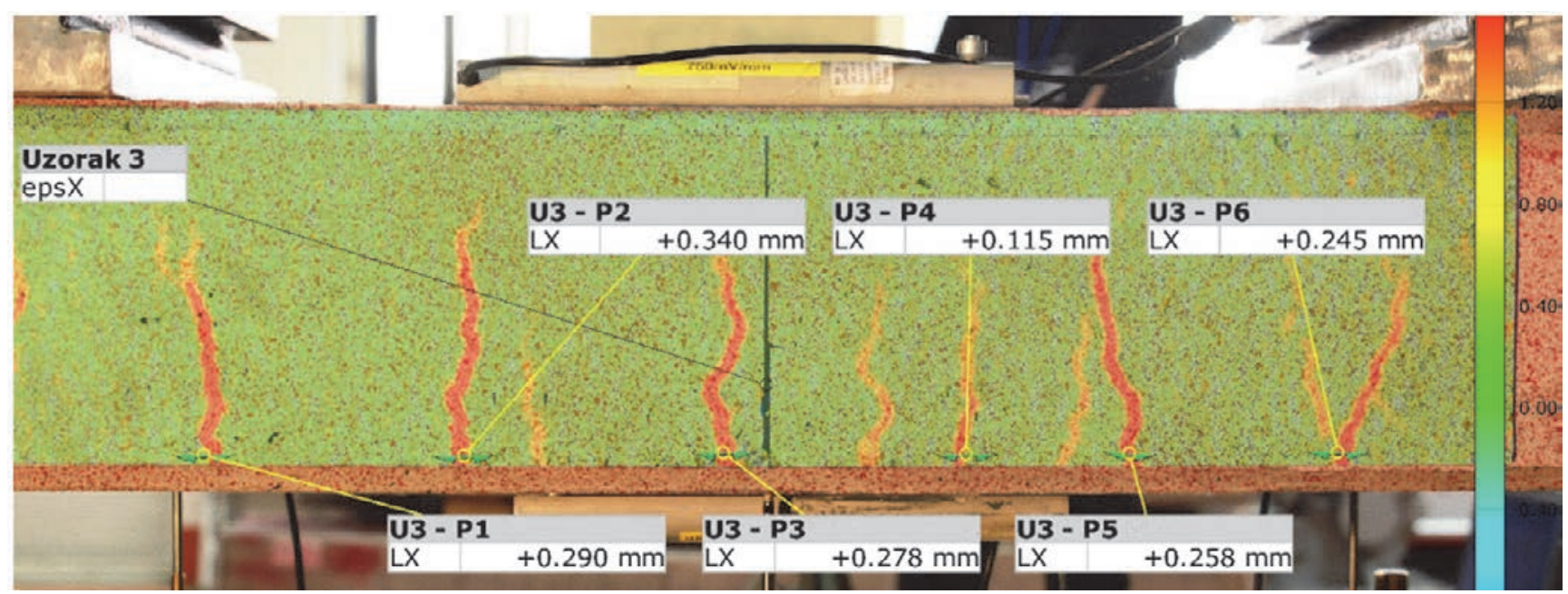

Figure 17. Graphical crack display obtained by DIC at specimen U3

Figures 18, 20, and 22 show crack width comparison for the measurement base of $200 \mathrm{~mm}$, obtained by both methods until the LVDT sensor detachment from the specimen surface. Relatively good agreement between the results can

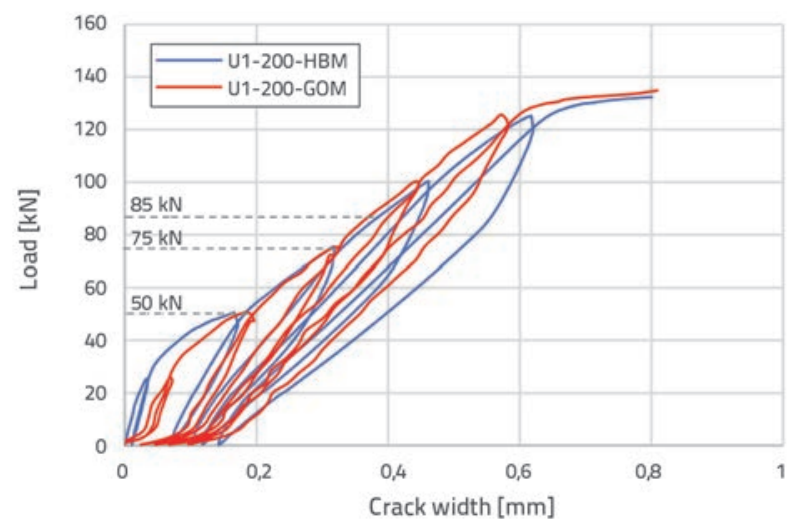

Figure 18. Crack width comparison for specimen U1 (until LVDT was detached) be noted. It should be mentioned that LVDT sensor results were obtained at the bottom specimen surface where the sensor was placed. The DIC results refer to the side surface of the specimen, which can explain a minor deviation of

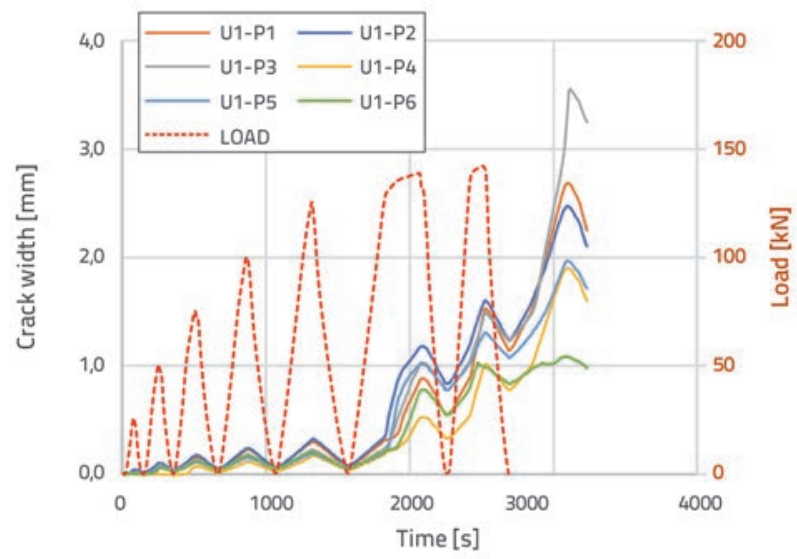

Figure 19. Width of selected cracks over time for specimen U1 (DIC) 


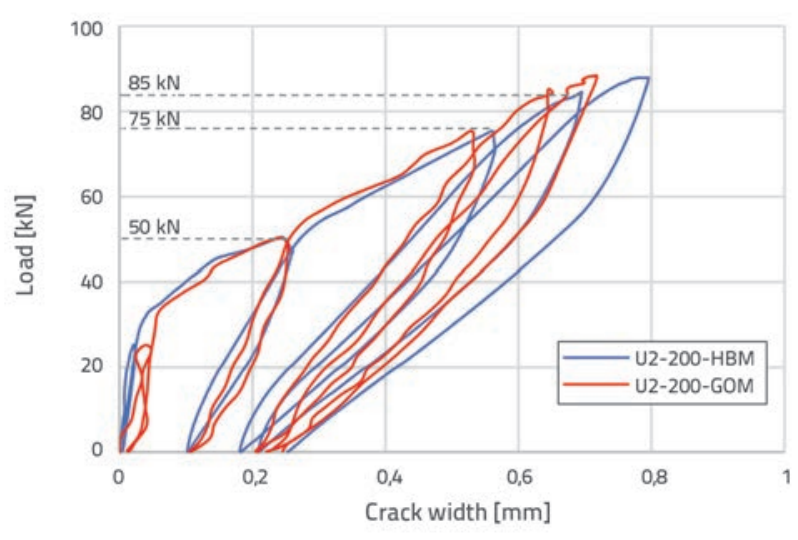

Figure 20. Crack width comparison for specimen U2 (until LVDT was detached)

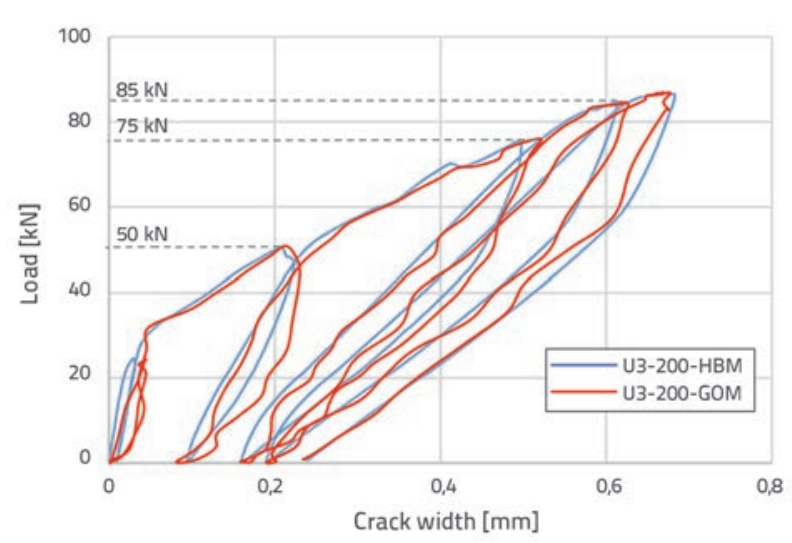

Figure 22. Crack width comparison for specimen U3 (until LVDT was detached)

results. These results are related to the total width of cracks measured at the $200 \mathrm{~mm}$ base. LVDT sensor detached from surface, due to large deformations, at the crack width of approx. $0.8 \mathrm{~mm}$ and so further measurement was made using DIC only. Figures 19, 21, and 23 show six largest cracks and their development over time on each specimen. It can be seen that more cracks opened at specimen U1, but they were smaller and thinner, while only one or two dominant cracks were noted at specimens $\mathrm{U} 2$ and $\mathrm{U} 3$. This is probably due to a smaller amount of reinforcement in specimens $U 2$ and $U 3$, see Figure 4.

\section{Analysis of test results}

The results obtained by the two methods were compared at several load levels for all specimens. Table 6 shows comparison of vertical displacements in the middle of

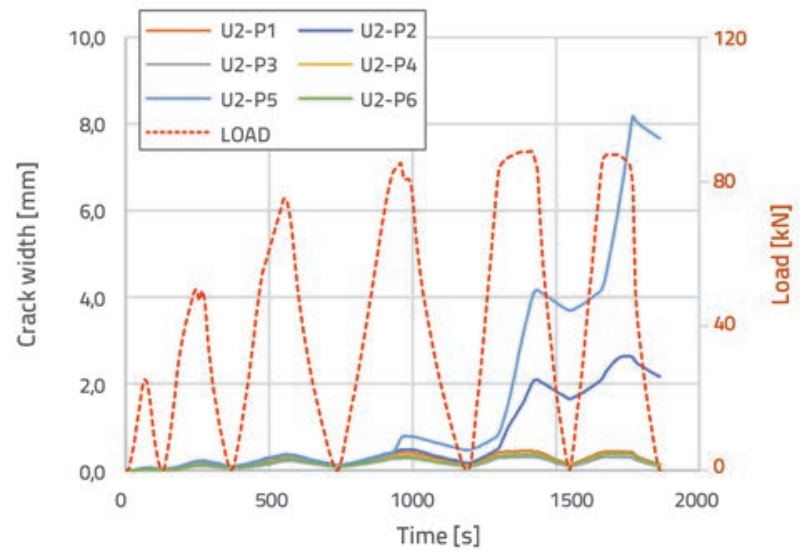

Figure 21. Width of selected cracks over time for specimen U2 (DIC)

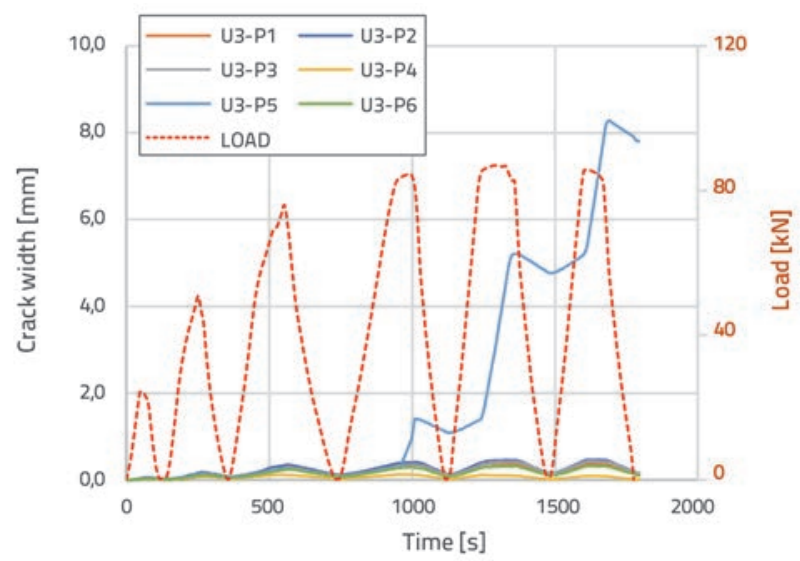

Figure 23. Width of selected cracks over time for specimen U3 (DIC)

the span. DIC results deviate from LVDT sensor results by only $\pm 1 \%$, except at low load levels where deviations of up to $3.3 \%$ were noted. Table 7 shows comparison of crack widths on the $200 \mathrm{~mm}$ measurement base. It can be noted that DIC results differ by up to $7 \%$ compared to LVDT results.

Some larger deviations were observed at lower load levels, at very small deformations, where maximum deviations amounted to $15 \%$. It should be stressed that these values were not measured at exactly the same places, as LVDT sensor was placed at the bottom surface and DIC measurement was performed at the side surface of the specimen. It was not possible to place LVDT in the DIC area because its body would cover the surface that was being analysed. Nevertheless, the analysis shows a relatively good correspondence of results. Comparison of results is shown in figures 24 and 25. 
Table 6. Comparison of displacements at different load levels

\begin{tabular}{|c|c|c|c|c|c|}
\hline $\begin{array}{l}\text { Load } \\
{[\mathrm{kN}]}\end{array}$ & $\begin{array}{c}\text { Specimen/ } \\
\text { measurement point }\end{array}$ & $\begin{array}{c}\text { Displacement HBM } \\
{[\mathrm{mm}]}\end{array}$ & $\begin{array}{l}\text { Displacement GOM } \\
{[\mathrm{mm}]}\end{array}$ & $\begin{array}{l}\text { DIC method deviation } \\
{[\%]}\end{array}$ & $\begin{array}{c}\text { Absolute deviation } \\
{[\text { [mm] }}\end{array}$ \\
\hline \multirow{3}{*}{25} & U1 - V1 & 1,84 & 1,78 & $-3,3$ & $-0,06$ \\
\hline & U2 - V1 & 1,92 & 1,90 & $-1,0$ & $-0,02$ \\
\hline & U3 - V1 & 1,90 & 1,89 & $-0,5$ & $-0,01$ \\
\hline \multirow{3}{*}{50} & U1 - V1 & 4,34 & 4,29 & $-1,2$ & $-0,05$ \\
\hline & U2 - V1 & 5,61 & 5,67 & $+1,1$ & $+0,06$ \\
\hline & U3 - V1 & 5,47 & 5,43 & $-0,7$ & $-0,04$ \\
\hline \multirow{3}{*}{75} & U1 - V1 & 7,65 & 7,64 & $-0,1$ & $-0,01$ \\
\hline & U2 - V1 & 10,45 & 10,55 & $+1,0$ & $+0,10$ \\
\hline & U3 - V1 & 11,25 & 11,21 & $-0,4$ & $-0,04$ \\
\hline
\end{tabular}

Table 7. Crack width comparison at different load levels

\begin{tabular}{|c|c|c|c|c|c|}
\hline $\begin{array}{l}\text { Load } \\
{[\mathrm{kN}]}\end{array}$ & $\begin{array}{c}\text { Specimen/ } \\
\text { measurement point }\end{array}$ & $\begin{array}{c}\text { Crack width HBM } \\
{[\mathrm{mm}]}\end{array}$ & $\begin{array}{c}\text { Crack width GOM } \\
{[\mathrm{mm}]}\end{array}$ & $\begin{array}{c}\text { DIC method deviation } \\
{[\%]}\end{array}$ & $\begin{array}{c}\text { Absolute deviation } \\
{[\mathrm{mm}]}\end{array}$ \\
\hline \multirow{3}{*}{50} & U1 - 200 & 0,162 & 0,186 & $+14,8$ & $+0,024$ \\
\hline & U2 - 200 & 0,236 & 0,253 & $+7,2$ & $+0,017$ \\
\hline & U3 - 200 & 0,223 & 0,257 & $+15,2$ & $+0,034$ \\
\hline \multirow{3}{*}{75} & U1 - 200 & 0,314 & 0,325 & $+3,5$ & $+0,011$ \\
\hline & U2 - 200 & 0,559 & 0,526 & $-5,9$ & $-0,033$ \\
\hline & U3 - 200 & 0,497 & 0,518 & $+4,2$ & $+0,021$ \\
\hline \multirow{3}{*}{85} & U1 - 200 & 0,386 & 0,373 & $-3,4$ & $-0,013$ \\
\hline & U2 - 200 & 0,694 & 0,645 & $-7,1$ & $-0,049$ \\
\hline & U3 - 200 & 0,613 & 0,615 & $+0,3$ & $+0,002$ \\
\hline
\end{tabular}

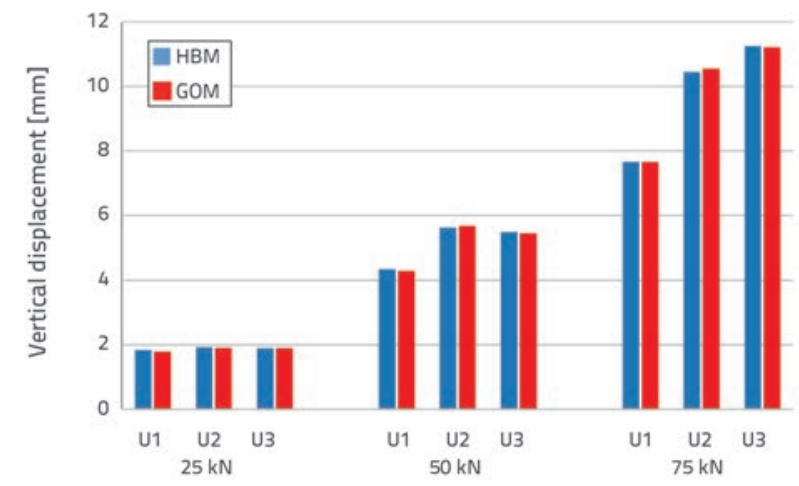

Figure 24. Displacement comparison

\section{Conclusion}

2D Digital Image Correlation (DIC) offers several advantages at measuring displacement and crack width, when compared to the conventional measuring technique with LVDT sensors. The great advantage of this method is its ability to monitor every crack separately no matter where it opens. Also, it enables crack

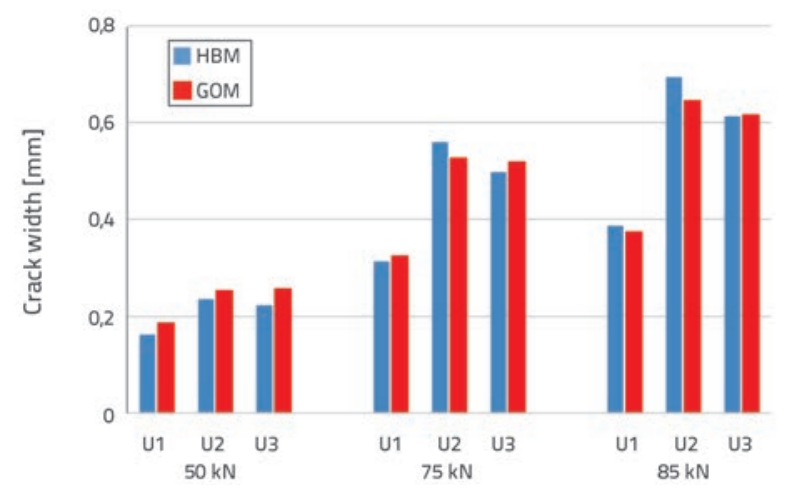

Figure 25. Crack width comparison

monitoring even at very large displacements, when LVDT sensors usually detach from the specimen. The greatest advantage of DIC is the cost of equipment, as it requires only a digital camera, personal computer, and free version of a commercial photo processing program. Conventional measurement with LVDT sensors is much more expensive because of the price of sensors and data acquisition system. 
The main objective of this research was to evaluate accuracy of $2 \mathrm{D}$ DIC results as compared to results obtained by LVDT sensors. The analysis of results shows that the DIC method deviates by only $\pm 1 \%$, except at lower load levels where deviations may attain 3\%. Furthermore, DIC crack width results differ by up to $7 \%$ compared to LVDT sensor results, except at lower load levels where deviations may reach up to $15 \%$. Continuous crack monitoring results are also shown, which is a considerable advantage when compared to conventional measuring techniques. The DIC method has proven to be quite simple to use, cost effective, and sufficiently accurate.

\section{REFERENCES}

[1] Mccormick, N., Lord, J.: Digital Image Correlation, Materials Today, 13 (2010) 12, pp. 52-54, https://doi.org/10.1016/S13697021(10)70235-2

[2] Frančić Smrkić, M.: Otpornost betonskih elemenata armiranih recikliranim čeličnim vlaknima pri zamoru, Disertacija, Sveučilište u Zagrebu, Građevinski fakultet, 2017.

[3] Mccormick, N.: Digital image correlation for structural measurements, Proc Inst Civ Eng, 165 (2012) 4, pp. 185-190, https://doi.org/10.1680/cien.11.00040

[4] Küntz, M., Jolin, M., Bastien, J., Perez, F., Hild, F.: Digital image correlation analysis of crack behavior in a reinforced concrete beam during a load test, Canadian Journal of Civil Engineering, 33 (2006) 11, pp. 1418-1425, https://doi.org/10.1139//06-106

[5] GOM Correlate Software, [Internet] [cited 2018 Mar 10]. Available from: https://www.gom.com/3d-software/gom-correlate.html

\section{Acknowledgements}

The authors wish to acknowledge financial support granted in the scope of the $7^{\text {th }}$ Framework Programme of the European Community "Innovative Use of All Tyre Components in Concrete". under contract number 603722. The authors gratefully acknowledge the support from all participants in the above mentioned project with special thanks to colleagues from the Faculty of Civil Engineering Zagreb Department of Engineering Mechanics, and the company Gradmont d.o.o.

[6] Frančić Smrkić, M., Damjanović, D., Baričević, A.: Application of recycled steel fibres in concrete elements subjected to fatigue loading, GRADEVINAR, 69 (2017) 10, pp. 893-905, doi: https://doi. org/10.14256/JCE.2059.2017

[7] HZN: HRN EN 12390-3:2012. Ispitivanje očvrsloga betona- 3. dio: Tlačna čvrstoća ispitnih uzoraka, 2012.

[8] HZN: HRN EN ISO 15630-1:2010 Čelik za armiranje i prednapinjanje betona - Metode ispitivanja - 1. dio: Armaturne šipke, valjana žica i žica, 2010.

[9] HZN: HRN EN ISO 6892-1:2016 Metalni materijali - Vlačno ispitivanje - 1. dio: Metoda ispitivanja pri sobnoj temperaturi, 2016.

[10] Canon EF-S Lens Review, [Internet] [cited 2018 Mar 10]. Available from: https://www.imaging-resource.com/lenses/canon/ef-s18-55mm-f3.5-5.6-is-stm/review/ 